特集 : 医療と膜

\title{
期限切れ濃厚赤血球由来へモグロビンを内包した リポソームタイプ人工赤血球の開発
}

\author{
後藤 博・浅川芳和・筒井洋治・大木紀子 \\ 木村哲寛・緒方嘉貴・上谷利治
}

テルモ株式会社研究開発センター 画 259-01 神奈川県足柄上郡中井町井ノロ 1500

\section{Development of the liposome encapsulated stroma free hemoglobin (SFH) from out dated human red blood cells as the blood substitute.}

\section{Hiroshi Goto, Yoshikazu Asakawa, Youji Tsutsui, Noriko Ohki, Tetsuhiro Kimura, Yoshitaka Ogata, Toshiharu Kamitani}

\author{
R \& D Center TERUMO CORPORATION, \\ 1500 Inokuchi, Nakai-machi, Ashigarakami-gun, Kanagawa
}

We have developed and evaluated the liposome encapsulated high-concentrated (>45\%) stroma free hemoglobin ( $\mathrm{SFH})$ : Neo Red Cell (NRC). SFH was encapsulated together with inositol-hexaphosphate (as an allosteric effector), coenzyme and substrates for reducing metHb back to oxyHb in liposomes. The NRC was subsequently coated with polyethylene glycol bound phosphatidylethanolamine as surface modifier to prevent aggregation of NRC in plasma. The oxygen affinity and the transport efficiency of NRC could be controlled as equal or more than those of the erythrocyte. The metHb formation was reduced $1 \% / \mathrm{hr}$ to $0.3 \% / \mathrm{hr}$ by the addition of metHb reduction system. The blood pressure increased transiently during injection, and then immediately returned to preinjection level. Our observations suggest that the NRC are efficient oxygen carriers without causing serious adverse reactions, with controllable metHb formation in vivo and during storage.

Key words : Liposome, Red blood cell substitute, Encapsulated hemoglobin, Enzymatic reduction system

\section{1.はじめに}

現在の外科治療において，輸血は欠かすことの
できない最も有効な手段の1つではあるが, 1) ウ イルス感染, GVHD 等の副作用の危険が有る. 2)緊急輸血時に血液型判定等が煩雑である. 3) 血 


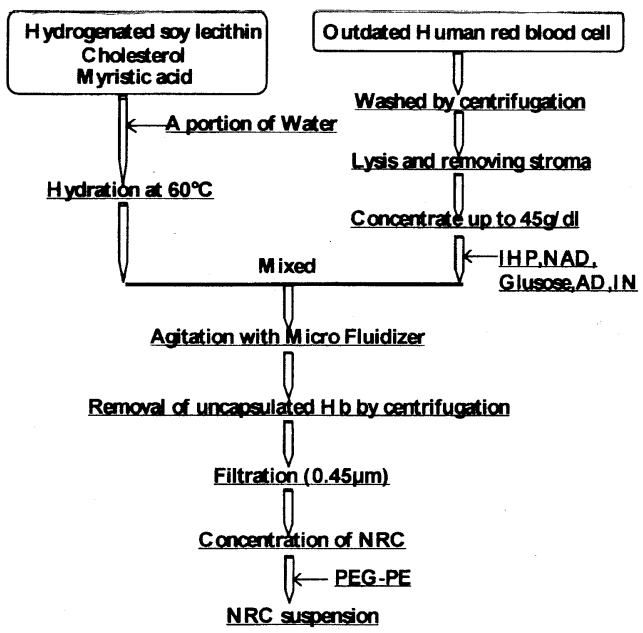

Fig. 1. The preparation of NRC.

液の長期保存ができない等, 輸血におけるリスク が存在する事は否定できない口．そこでこれらの リスクを回避するために血液に代わる血液代替物 の開発が進められてきた. 血液代替物として血漿, 酸素運搬体, 血小板等の研究がなされているが, 特に人工の酸素運搬体が古くから注目を浴び, 精 力的に研究が成されている. 現在人工酸素運搬体 としてはへモグロビンを使用した人工酸素運搬体 が研究の主流となっているが，その中でへモグロ ビンに何等かの化学的修飾を加え酸素運搬能, 血 中寿命, 毒性等を改善した溶液 $\mathrm{Hb}$ タイプの人工 酸素運搬体あるいはリポソーム等でへモグロビン をカプセル化した人工酸素運搬体が研究の中心と なっている ${ }^{2)}$. 米国における血液代替物は主にこ の溶液 $\mathrm{Hb}$ タイプが主流であり臨床例も多く存在 するが，そこで投与後に血管収縮により血圧が上 昇する等の副作用が問題となっている ${ }^{3)}$ 。これは 血管内皮の血管収縮抑制因子である NO をへモ グロビンがトラップすることに起因すると考えら れている，そこで生体にたいする影響をより少な くするために, 生体膜に近い構造を持ち, さらに ある程度の大きさ（0.2 $\mu$ 程度）をもつために内 皮との相互作用が少なく, 投与しても血管収縮に よる血圧上昇を引き起こしにくいと考えられるリ ポソームタイプの血液代替物が現在注目されてい る. 我々の開発した人工酸素運搬体 Neo Red

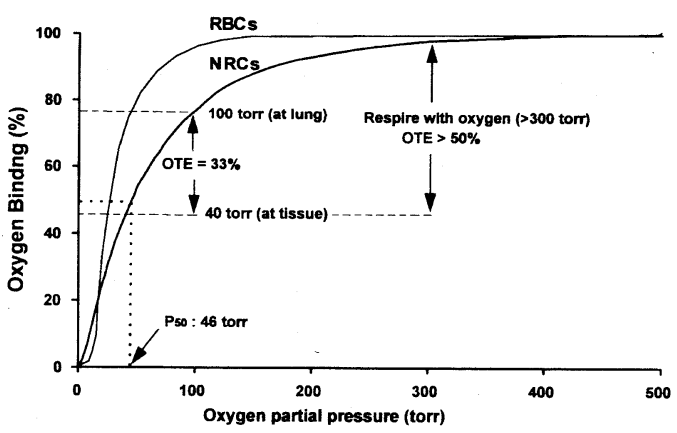

Fig. 2. Oxygen-dissociation curves of Red Cells and NRC

Cell (NRC) は高濃度のへモグロビン溶液を, 酸 素親和性をコントロールするためのアロステリッ クエフェクターとしてイノシトールヘキサホス フェイト (IHP) と, ヘモグロビンの酸化を抑制 するために赤血球由来の嫌気的糖代謝系酵素之気 質および補酵素と共に, 水素添加大豆レシチン, コレステロール, ミリスチン酸からなるリポソー ムによりカプセル化したリポソームタイプの血液 代替物である ${ }^{4)}$. さらに血漿中で凝集しやすいと いうリポソームの欠点を改善するためにリポソー ム膜の表面に PEG 鎖を結合していることも大き な特徴となっている.

\section{NRC の調製}

厚生省を通じて日赤より入手した期限切れ濃厚 赤血球製剂 $(\mathrm{CRC})$ から, 赤血球膜除去へモグロ ビン溶液（ストローマフリーへモグロビン: SFH） を調製し, 濃度を $45 \%$ まで高めた後, 水素添加 大豆レシチン, コレステロール, ミリスチン酸か らなる混合脂質を加えて, 乳化機でへモグロビン を IHP および補酵素, 基質等とともにリポソー ム化し,カプセル化されなかった Hb を除去, フィ ルターにより粒径を制御した後, $\mathrm{Hb}$ 濃度 $6 \mathrm{~g} / \mathrm{d} l$ に濃縮し NRC サスペンションを得た (Fig 1).

\section{NRC の酸素解離曲線}

ヒト血液は赤血球中に存在している 2,3 -ホス ホグリセリン酸 $(2,3-\mathrm{DPG})$ によってへモグロ 


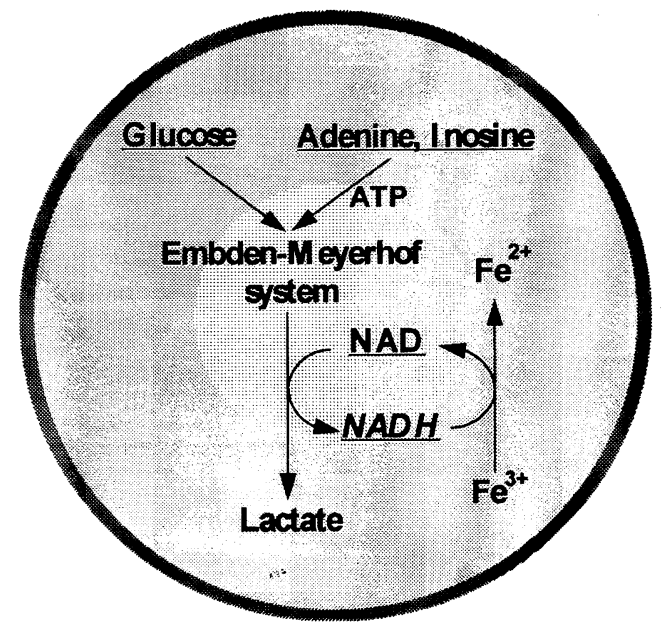

Fig. 3. The Schematic and model of the met $\mathrm{Hb}$ reduction system in NRC.

ビンの酸素親和性を制御している.これによって, 酸素分圧の低い末梢血管で効率的に酸素の放出が 行われる. 期限切れの濃厚赤血球中ではこの 2 , 3-DPG がほとんど代謝, 消失しており, さらに SFH の調製工程で完全に 2, 3-DPG が取り除か れてしまうために，このままの SFH では酸素親 和性が非常に高く(P50：12 torr) なってしまい 酸素を抹消でも離さなくなるため酸素運搬体とし て適していない，そこで NRCでは SFH にアロ ステリックエフェクターとして IHP を添加する ことで酸素親和力をコントロールし, 天然の赤血 球に比較して高い酸素運搬効率（酸素分圧 100 $\mathrm{mmHg}-40 \mathrm{mmHg}$ 間のへモグロビン酸素飽和 度差が NRC : $30-35 \%$, 赤血球 : 約 26\%）を得 ている，特に酸素濃度を高くした場合 (300 torr 程度）には酸素運搬効率は $50 \%$ 以上となり赤血 球のおよそ 2 倍に達する ${ }^{5)}$ (Fig. 2).

\section{4. メトヘモグロビンの還元}

天然の赤血球では内部に還元機構を有するため に, 生体内では酸化したメトへモグロビンは常に 1\%以下に抑えられている. 赤血球の糖代謝系 （Embden-Meyerhof 系）に着目し，これらの酵 素活性を維持した SFH を調製し，これに基質お

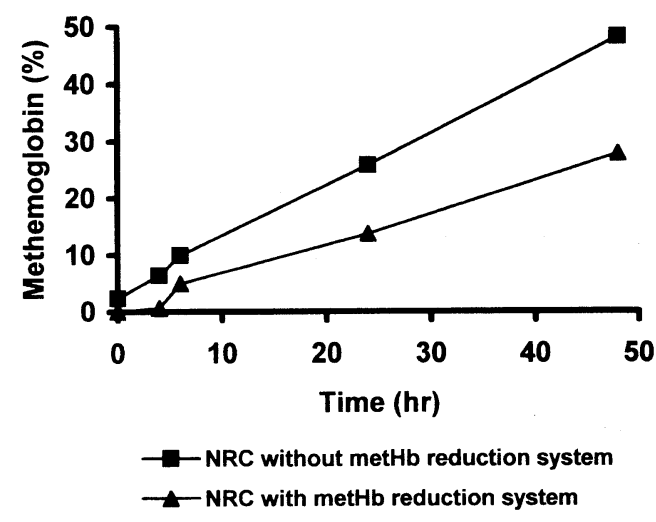

Fig. 4. The metHb formation of NRC. (in vitro at $37^{\circ} \mathrm{C}$ )

よび補酵素として NAD, グルコース，アデニン， イノシン等を添加し NRC を調製することで (Fig. 3), NRC 中において嫌気的糖代謝系を作動させ ることに成功し NRC のへモグロビンのメト化の 抑制に成功した ${ }^{6)}$ (Fig: 4).

\section{NRC の表面修節}

一般的にリポソームは血漿中で凝集する傾向が ある．そこでNRCでは平均分子量 5,000 のポリ エチレングリコールとリン脂質を結合させた表面 修飾剂 (PE-PEG) で NRC の膜表面を修飾し, PEG の排除体積効果によって膜表面へのタンパ クの吸着を抑えることで, 血漿中での NRC の凝 集防止を可能にした7).

\section{NRC の In-Vivo 評価}

\section{1 出血ショックに対する効果}

ウサギを用いてその血圧を $50 \mathrm{mmHg}$ 以下に 90 分間保ち, 出血ショックモデルを作成し, 出 血ショックに対する NRC の効果を評価した (Fig. 5). 出血ショックによる血圧の低下からの回復 に，同種血および HES 溶液に比べ NRC 投与例 は優れていた ${ }^{8)}$. 

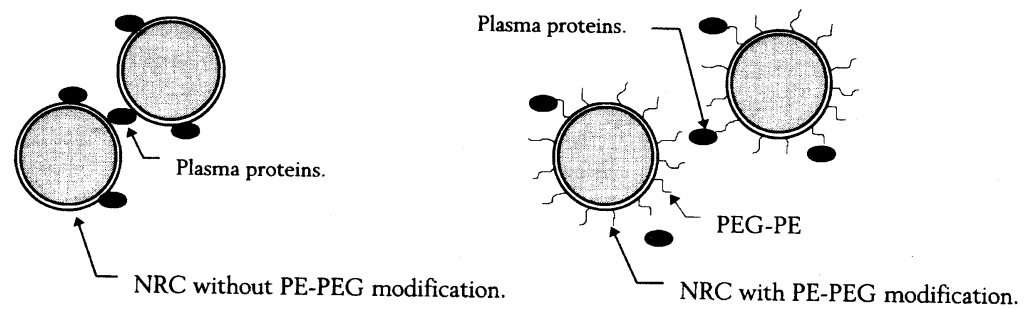

Fig. 5. The Schematic model of the liposome coagulation depends on the adsoption of plasma proteins.

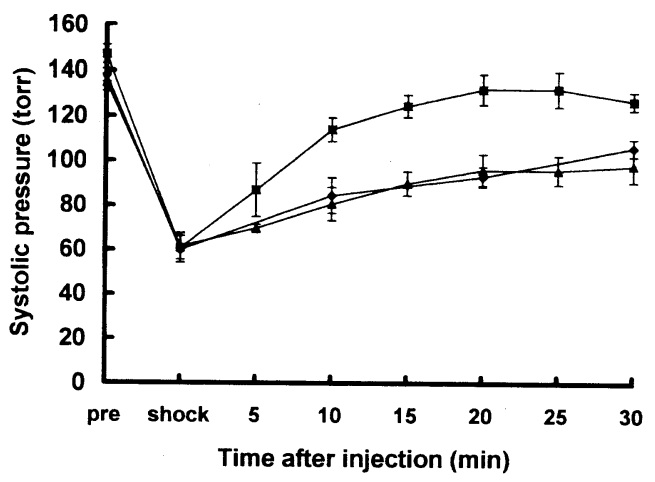

$\rightarrow$ HES $\rightarrow$ Blood $\rightarrow$ NRC

Fig. 6. The effect of NRC infusion on hemorrhagic shock.

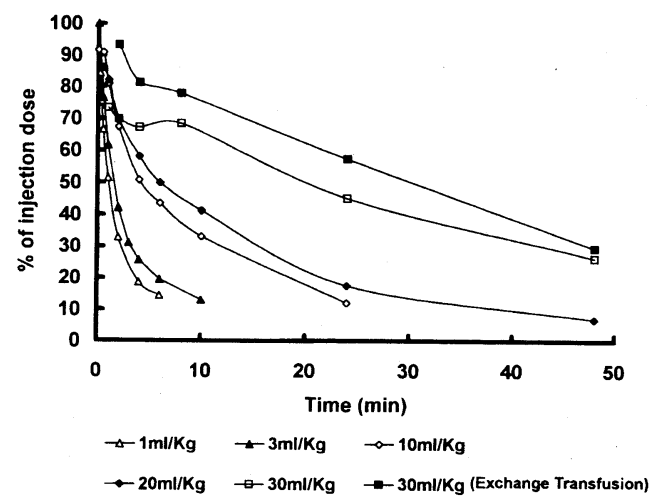

Fig. 8. The clearance from the circulation of ${ }^{14} \mathrm{C}$-labeled NRC, at different dose.

\section{2 NRC 投与の血圧におよぼす影響}

ラットに対して $\mathrm{NRC}, \mathrm{SFH}$, 生理食塩水, 血 液を投与し血圧にたいする影響を調べた。 その結 果 SFH 投与系では血圧の上昇が観察されたが, $\mathrm{NRC}$ 投与例では投与中の一時的な上昇にとよ゙

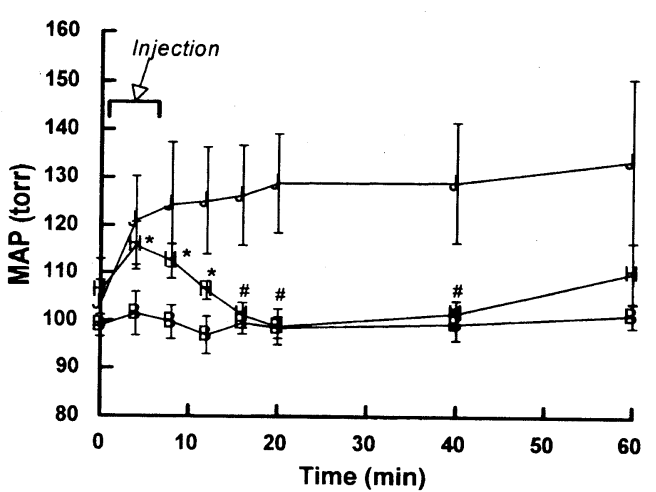

$\mathrm{J}:$ SFH H : NRC B : Saline

Fig. 7. The effect of NRC injection on the blood pressure in conscious rats.

まった (Fig. 7).

6. $3 \mathrm{NRC}$ 投与後の体内動態, 網内系貪食能 におよぼす影響

$\mathrm{NRC}$ の体内動態を $\mathrm{RI}$ 標識 $\left({ }^{14} \mathrm{C}\right.$ 標識 $\left.\mathrm{DPPC}\right)$ した $\mathrm{NRC}$ を調製し，NRC 投与後の体内動態を 測定した ${ }^{9)}$ (Fig. 7). さらに NRC 投与が網内系 (Reticuloendothelial system, RES) の領食能 におよぼす影響を carbon clearance 法により測 定した，NRC を投与した後の RES 領食能は投 与量 $40 \mathrm{mg} / \mathrm{ml}$ 以上では一時的に低下するが, 1 日以内に回復することが示唆され, 貪食能に与え る影響は小さいと考えられた。 また血中からの $\mathrm{NRC}$ の消失は主として網内系の貪食作用による ものであり，NRC をマウスに投与した際の網内 系臓器における NRC 由来のヒトへモグロビンは 7 日以内に検出されなくなり, NRC の速やかな 
分解が示された ${ }^{9)}$.

\section{NRC の生体適合性}

\section{1 凝固系におよぼす影響}

血液凝固反応において，リン脂質の存在下で凝 固因子が活性を増幅する段階があることなど，血 液凝固においてリン脂質は重要な役割を持ってい る. NRC が血液凝固機能に与える影響について in vitroで実験を行った。 ヒト血漿と等量（容量 比）の $\mathrm{NRC}$ を混合して, $37^{\circ} \mathrm{C}$ でインキュベイ トし，活性部分トロンボプラスチン時間 (AP $\mathrm{TT})$, プロトロンビン時間 (PT) を測定した。 そ の結果 NRC が血漿中に混在することによる凝固 反応の阻害は認められなかった ${ }^{10)}$.

\section{2 補体系におよぼす影響}

新鮮ヒト血漿と NRC を容積比 4:1 で混合し て $37^{\circ} \mathrm{C} 60$ 分, インキュベイトし補体分解産物 C3a，C4a の生成量を測定した. 補体活性の陽性 コントロールとして生理食塩水に, $5 \mathrm{mg} / \mathrm{ml}$ で 懸濁させた zymosan (SIGMA), 陰性コント ロールとして生理食塩水を使用した，NRCによ る C3a, C4a の生成は認められなかった ${ }^{10)}$.

\section{8. おわりに}

$\mathrm{NRC}$ がリポソームタイプの人工赤血球である ことを特徴としているため, へモグロビンと共に 様々な物資をリポソームによりカプセル化する事 が可能となった。 そこで我々は天然の赤血球を上 回る酸素運搬能を得るために IHP をアロステ リックエフェクターとして用い, 酸素濃度の高い ところでは赤血球の約 2 倍の運搬効率を得る事に 成功した。 また，へモグロビンと共に赤血球由来 の嫌気的糖代謝系酵素, 補酵素, 基質をカプセル 化しへモグロビンの酸化抑制にも成功した.

またリポソームの大きさは赤血球の $5 \mu \mathrm{m}$ に比 較して $0.2 \mu \mathrm{m}$ と小さく, さらに粘度が血液と比 較して低いために出血ショック時などの抹消の血 管が閉じてしまっているような場合でも血流が回
復しやすくショックからの血圧の回復に優れてい る事が判った。また，リポソームという膜でへモ グロビンを包んでいるために，へモグロビンその ままを投与した場合に問題となる血圧上昇の副作 用を低減する事が出来た。 また，大量に投与した 場合でもその毒性は低く, 投与動物の主要臓器に 大きな問題は無い事を確認している.

以上, NCR はへモグロビンを用いた人工の酸 素運搬体として溶液タイプのへモグロビンの持つ 欠点を, リポソームという生体適合性に優れた脂 質二分子膜でカプセル化する事で改善し, 優れた 酸素運搬能と安全性を兼亦備えた次世代の人工酸 素運搬体であると考えられる.

\section{参考文献}

1）大柳治正, 斉藤洋一, 人工血液研究の現状, 臨㦿 医学, 21, 770, 1986.

2）土田英俊, 武岡真司, 血液代替物：最近の進歩, 人工血液 $1,5-10,1993$

3) FDA Draft Point to Consider in the Safety Evaluation of Hemoglobin-Based Oxygen Carriers, Cen Biologies Eval Res, HDA Aug, 27, 1990

4）鈴木一比好, 後藤博, 緒方嘉貴, 坂口圭介, 岡本 武, 上谷利治, 高橋晃, リポソーム型人工赤血球 (NRC), 人工血液 2,39-40, 1994

5）緒方嘉貴, 後藤博, 坂口圭介, 鈴木一比好, 上谷 利治, 高度交換出血モデルによるネオレッドセル (NRC) の機能と安全性, 人工臟器, 22, 1157-1161, 1993

6）緒方嘉貴, 岡本武, Methemoglobin 還元機構を 有した人工赤血球 (NRC) の開発, 人工血液 $\mathbf{2}$, 62-66, 1994

7）吉岡浩, 鈴木一比好, 宮内雄二, 人工赤血球少术 ソームの PEG 表面修飾による血漿中凝集防止, 日本膜学会, 11 年会講演要旨集, 49,1989

8) Ogata Y, Goto H, Sakaguchi K, Suzuki M, Ohaki K, Kamitani T, Takahashi A, Characterristics of Neo Red Cells, their function and safty : in vivo studies. Biomater Artif cells Immobilization Biotechnol (in press)

9）坂口圭介, 緒方嘉貴, 鈴木雅弘, 鈴木一比好, 高 橋晃, NCR 静脈投与後の体内分布及び網内系領食 能に対する影響, 人工臟器, 22, 560-565, 1993

10）坂口圭介, 宮内雄二, 鈴木一比好, 高橋晃, ネオ レッドセルの血液凝固系・補体系に及ぼす影響, 人工臟器, 20,620-625, 1991

（受付 1995 年 5 月 17 日） 